\title{
TYPE LOCALITIES FOR SIX SPECIES OF TASMANIAN LAND MOLLUSCS (PULMONATA:STYLOMMATOPHORA)
}

\author{
by Ron C. Kershaw
}

KERSHAW, R.C., 1987 (30:vi): Type localities for six species of land molluscs (Pulmonata: Stylommatophora). Pap. Proc. R. Soc. Tasm., 121: 57-68. https://doi.org/10.26749/rstpp.121.57

ISSN 0080-4703. Queen Victoria Museum, Wellington Street, Launceston 7250

Type localities are determined and described for the mollusc species Caryodes dufresnii (Leach 1815), Anoglypta launcestonensis (Reeve 1853), family Caryodidae; Bothriembryon tasmanicus (Pfeiffer 1853) and $B$. brachy'soma Pilsbry 1900, family Bulimulidae; and Cy'stopelta petterdi Tate 1881 and C. bicolor Petterd \& Hedley 1909, family Cystopeltidae from Tasmania. The determinations are supported by historical data.

Key Words: Tasmania, land molluscs, type localities, habitat.

\section{INTRODUCTION}

Study of the variation in several genera of land molluscs living in Tasmania suggests a relationship between the environment and snail morphs. In the process of distinguishing between mollusc species and varieties, it is essential to determine the types and type localities of the known taxa.

The aim of this paper is to determine or clarify and describe the type localities for species of the genera Caryodes, Anoglypta, Bothriembryon and Cystopelta. The types of the species Caryodes dufresnii (Leach 1815), Bothriembryon tasmanicus (Pfeiffer 1853), Cystopelta petterdi Tate 1881 and C. bicolor Petterd \& Hedley 1909 are unknown or have been lost. Descriptions of neotypes and voucher specimens will be presented elsewhere (Kershaw 1987, and in prep.).

The type localities for Cystopelta petterdi and $C$. bicolor are known approximately. The determinations here are concerned with neotype localities. The type locality of $C$. petterdi is now occupied by urban development. Those of Caryodes dufresnii, Anoglypta launcestonensis, Bothriembryon tasmanicus and $B$. brachysoma have not previously been accurately determined.

\section{METHODS}

The determinations here suggested are made on the basis of the criteria provided for in Recommendation $72 \mathrm{H}$ of the International Code of Zoological Nomenclature, Third Edition, 1985. Museums in Europe and America which may have held original material have been consulted. The original descriptions together with labels with possible original material where available, have provided valuable data.

Some localities are suggested by Iredale (1937a, 1937b) and Hedley (1891). The determinations and the habitat data are supported by fieldwork throughout Tasmania except for South Cape Bay and Maria Island. Information in these cases has come from other people and the literature. Recognition of vegetation types is based on the work of Jarman \& Brown (1983, rainforest), Gilbert (1959, mixed forest), Jackson (1974, wet sclerophyll) and Duncan \& Brown (1985, dry sclerophyll). Climatic data are presented in Appendix 1. Map references are based on the Topographical Survey of Tasmania, 1:100 000 series.

\section{CARYODES DUFRESNII}

$$
\text { (LEACH, 1815) }
$$

Proposed Type Locality:

Near South Cape Bay, southern Tasmania.

This species was described by Leach (1815) as Bulimus dufresnii, the brief description supplemented by a readily recognizable figure. The locality given by Leach was "Australasia" but the author also stated "Inhabits New Holland. The shell was named after $M$. Dufresne "in whose collection ... it occurs." Because of the name, consideration has been given to the expedition under the command of Captain Marion du Fresne in 1772 as the occasion of collection of the shell. This possibility and the distribution of shell forms led Kershaw \& Dartnall (1972) to consider southeastern Tasmania as a possible type locality.

\section{Original Material}

Leach (1815) clearly established that the shell described came from the collection of Louis $\mathrm{Du}$ 
Fresne. The history of this collection, which is partly lodged in Edinburgh and partly within the Delessert Collection in Geneva, is provided by Dance (1966). There is no specimen of Caryodes in the Delessert Collection (E. Binder in litt. 1977). There is no Caryodes specimen present in the Edinburgh Du Fresne Collection (D. Heppell in litt. 1977). Enquiries in London and Paris also failed to locate type material.

\section{French Expeditions}

McClymont (1885) listed eleven navigators, three of whom were French, who visited Van Diemen's Land. The evidence does not support collection by an English expedition. A close study of the visit of Marion du Fresne to the eastern Tasmanian coast described by Giblin (1928) suggests that his expedition is not likely to have collected the shell. His party made a frustrating search for water over a burnt landscape. Plomley (1984) has pointed out that the party collected only marine shells and du Fresne found the conditions inhospitable. No variations of Caryodes conforming to the Leach figure are known from the area of his landing.

There are records of Caryodes dufresnii collected by the French from eastern Tasmania. Peron, naturalist with the Baudin expedition (Giblin 1928, Plomley 1984) collected shells which are preserved in the Ferussac Collection in the Natural History Museum in Paris (S. Tiller in litt. 1977). Shell form and collection date render this as unlikely to be the source of Leach's shell.

This leaves the expedition of Admiral Bruni D'Entrecasteaux with the naturalist De Labillardiere in 1792 and 1793. The history of the landing at Recherche Bay has been described by Giblin (1928), Pretyman (1954) and Plomley (1984). Comment on the considerable collections does not appear to include snails but it is improbable that Caryodes shells were not seen. Labillardiere was a keen observer interested in all living things (Giblin 1928). In addition Labillardiere collected widely in the area from South Cape Bay to Southport Lagoon. Giblin also remarked that earlier navigators had little time for investigation due to other projects.

\section{Shell Form}

Caryodes dufresnii is well known for its shell variation. Three subspecies were described by Iredale (1937b) from Launceston, Port Davey and Macquarie Harbour. Of these the first has distinct features. Iredale thought that the type locality could be "north from Hobart" but this does not distinguish the species from other forms nor is there any evidence that the original specimen could have come from such a locality. Iredale's subspecies are based on illustrations by Tenison-Woods (1878).

The shell figured by Leach has a curious flattening of the basal margin partly due to a twist of the columella. No specimens exactly like this have been seen but shells with a twisted columella are known from southern Tasmania. Examples in the Tasmanian Museum collection include E9893 from Lune River and E4341 from Cox Bight both of which have some resemblance to the Leach figure. Specimens from South Cape Bay (E8591) have the basal margin more rounded than in the figure but these also have the twisted columella. The effect of the twist is to broaden the basal margin providing a distinctive appearance. Study of a large number of shells has not revealed equivalent material in a nother site from which the original material could have been collected.

Iredale (1937b) remarked on the twisted columellar margin present in a Ringarooma shell figured by Tenison-Woods $(1878,6 \mathrm{~b})$. In this case the basal margin is deeply curved as a result rather than broadened. However juvenile specimens also have a broadened a perture associated with a twisted columella (e.g. Tenison-Woods 1878, 6a). The belief that such shells are adult variations has caused confusion in the past. Therefore it has been necessary to study many shells before concluding that specimens from South Cape Bay have a satisfactory resemblance to the Leach figure.

\section{Locality Determination}

The specimens E8591 in the Tasmanian Museum came from wet forest "near South Cape Bay". National Parks and Wildlife Service staff working in the area have seen specimens (Rounsevell in litt. 1986) suggesting a viable population. Labillardiere (1800) described a view in February 1793 towards South Cape from the summit of a mountain. His party spent the night on the edge of the forest near a rivulet. They continued along the shore the next day noting a gentle slope of the back shore and a vein of coal (exposed in a cliff section at South Cape Bay) as they walked. They may have been near South Cape Rivulet but in any case there is no doubt that they traversed the region.

It is therefore possible that this party collected specimens of Caryodes in this area. This possibility is supported by a generalised resemblance between shells from the area and the figure of Leach (1815), 
together with the peculiar columellar marginal twist.

The region between Recherche Bay and South Cape Bay bounded by $43^{\circ} 31^{\prime} \mathrm{S}$ to $43^{\circ} 37^{\prime} \mathrm{S}$ and $146^{\circ} 44^{\prime} \mathrm{E}$ to $146^{\circ} 53^{\prime} \mathrm{E}$ is suggested as the type locality for Caryodes dufresnii (Leach 1815).

\section{The Habitat \\ Vegetation}

Caryodes dufresnii as here restricted is a snail of the wet forest. This environment includes rainforest, mixed and wet sclerophyll forests. It is not known to include open country, moorland, sedgeland or grassland communities. A large related form is found in wet forest throughout Tasmania (but not the Bass Strait Islands). Regional variation is apparent but the significance of this and the distribution of varieties has yet to be determined. Prior to European settlement the genus probably occupied every suitable habitat but the distribution is now much reduced (Smith \& Kershaw 1981).

Vegetation which may be encountered in the Caryodes habitat includes Nothofagus cunninghamii, Acacia melanoxylon, Acacia dealbata, Atherosperma moschatum, Anodopetalum biglandulosum, Pomaderris apetala, Pittosporum bicolor, Blechnum wattsii, Dicksonia antarctica and Leptospermum spp. The flora is mainly dominated by Eucalyptus obliqua or E. regnans and in places dominated by $E$. globulus, $E$. viminalis or $E$ delegatensis.

Twelvetrees $(1915 b)$ recorded a range of vegetation in the area of the proposed type locality suggesting that several suitable areas of habitat existed at the time of his visit. His observations are supported by data provided in Waterman \& Paterson (1981) and Kirkpatrick \& Backhouse (1983). Vegetation maps presented by Jackson (1965), Jarman \& Brown (1983) and Kirkpatrick \& Dickinson (1984) show that despite considerable modification since Labillardiere's observations extensive areas of forest persist.

Open eucalypt forest extends west from the surface developed on dolerite to that on sedimentary rocks of the Parmeener Supergroup near South Cape Bay, with closed scrub on the higher ground north from South Cape (Waterman \& Paterson 1981). The forest opens to sedgeland near the coast in the South East Cape area and an area of mixed forest has apparently survived in the valley of South Cape Rivulet. The Caryodes habitat can be expected to be in the eucalypt and mixed forest areas.

\section{Geology and Soils}

Accounts of the geology of the South Cape Bay and Recherche Bay region are given by Milligan (1849), Twelvetrees (1915a, 1915b) and Farmer (1979). The main rocks outcropping in the region are Jurassic dolerite, north from South East Cape to Recherche Bay, and Triassic sandstone and shale northeast from South Cape Bay to Recherche Bay. Narrow strips of Quaternary alluvium adjoin Cockle Creek and South Cape Rivulet. The soils (Nicolls \& Dimmock 1965) in the area are grey-brown podzolic on dolerite, gradational yellow podzolic soils on the sedimentary rocks and uniform profiles on the Holocene alluvial and dune sands.

\section{Climate}

Rainfall maps by the Bureau of Meteorology and Christian \& Sharp-Paul (1979) suggest an estimated $1400 \mathrm{~mm}$ annual rainfall in the South Cape Bay region. These authors showed that temperatures decrease with distance inland. Modern climatic data are available for Maatsuyker Island and Cape Bruny (Appendix 1). Nunez (1978) graphed rainfall for Maatsuyker Island and his figures provide some indication of rainfall reaching the coast.

\section{Microhabitat}

The habitat includes both litter and moss on the ground. The snail seeks shelter under logs particularly where litter has accumulated alongside the log. Litter accumulations against rock outcrops are also favoured. The snail may seek shelter in crevices and cavities of tree trunks in shaded forest and has been observed climbing trees during rain Some animals may be seen crawling in the open early in the day but seek shelter from sunlight.

\section{ANOGLYPTA LAUNCESTONENSIS (REEVE 1853)}

\section{Proposed Type Locality: Mt Maurice Forest Reserve}

The species was introduced by Reeve (1853a) as Helix launcestonensis and defined by a clear illustration. A description was provided separately (Reeve 1853b). In both cases the locality is given as "Launceston, Van Diemen's Land". However Reeve remarked "collected last summer by $\mathrm{Mr}$ Ronald Gunn in a dense beech forest, north-east of Launceston."

Launceston was accepted by Iredale (1937b) but clearly Reeve used the name as the nearest 
known locality of which he was aware. His concept of the type locality is clear in the remarks made. The purpose here is to establish this locality. The species is considered at risk (Wells et al. 1983) and an area providing adequate security for an existing population should be defined.

\section{Original Material and Locality Determination}

Two lots of specimens regarded as syntypes are preserved in the British Museum of Natural History. The original label does not refer to Gunn but Dr P. Mordan (in litt. 1986) is confident that these are the type series. The label gives the locality as "V. D. Land". Fortunately Gunn's correspondence (Burns \& Skemp 1961) with Sir William Hooker strongly supports the probability that he did collect the material and indicates the locality involved. In a letter dated 17th March 1849, Gunn described a walk "through a forest of Fagus Cunninghamii towards the North-East", in October 1848. A letter to Hooker dated 10th May 1849 explains that Gunn had "opened a communication with $\mathrm{Mr}$ Lovell Reeve" although no mention is made of the snail shells.

The route taken by Gunn is shown by Burns \& Skemp (1961, opp. p.18) as proceeding from Diddleum Plains towards the northeast through myrtle forest. Diddleum was a point of entrance to "the unknown territory"( Hookway et al. 1981) and Gunn had a summer sheep run there. Hence there is no doubt as to Gunn's starting point.

The route followed by Gunn passes to the east of Mt Maurice to the valley of the Ringarooma River. This is a similar route to that now followed by the Maurice Road. It is impossible to determine the exact site from which Gunn's shells came. The species is present at a number of sites along and surrounding the route. In order to include as far as possible, the original site together with known existing populations and the Forest Reserve it is necessary to define an area larger than the Reserve.

Therefore the type locality for Anoglypta launcestonensis (Reeve 1853) is thought to lie within an area in northeastern Tasmania between Mount Scott and Trenah bounded by $41^{\circ} 15^{\prime} \mathrm{S}$ to $41^{\circ} 21^{\prime} \mathrm{S}$ and $147^{\circ} 31^{\prime} \mathrm{E}$ to $147^{\circ} 40^{\prime} \mathrm{E}$.

\section{The Habitat}

\section{Vegetation}

Anoglypta launcestonensis is found in scattered localities within rainforest and mixed forest in areas having an annual rainfall approxi- mating $1400 \mathrm{~mm}$ or more extending from $\mathrm{Mt}$ Arthur easterly to just east of Goulds Country. This region is bounded by $41^{\circ} 10^{\prime} \mathrm{S}$ to $41^{\circ} 25^{\prime} \mathrm{S}$ and $147^{\circ} 16^{\prime} \mathrm{E}$ to $148^{\circ} 05^{\circ} \mathrm{E}$. A copy of a report on field work done in the region is held by the Queen Victoria Museum (Smith \& Kershaw, unpub.).

In the type area the following species occur: Eucalyptus delegatensis, Nothofagus cunninghamii, Phyllocladus aspleniifolius, Atherosperma moschatum, Tasmannia lanceolata, Blechnum sp. and Persoonia sp. Also observed in the habitat are Eucalyptus regnans, E. obliqa, Pomaderris apetala, Dicksonia antarctica and Polystichum proliferum. Much of the habitat is included in the land systems Diddleum Plains and Mt Maurice (Pinkard 1980). The former according to Pinkard is dominated by Nothofagus and sassafras and the latter by eucalypts.

\section{Geology and Soils}

The rock cropping out in the type locality is Devonian granodiorite (McClenaghan \& Baillie 1975). The soils are yellow gradational podzolic with a clay B horizon (Nicolls \& Dimmock 1965). The A horizon is highly organic and shallow with a moss cover or, where eucalypts dominate, a deeper litter cover.

\section{Climate}

The annual precipitation is similar to that required for survival of rainforest trees, i.e. 1400 $\mathrm{mm}$ (Jackson 1965). The $1400 \mathrm{~mm}$ isohyet almost encloses the distribution of Anoglypta launcestonensis. Successful populations are found in areas of apparently high rainfall reliability. The nearest rainfall figures available are those of Ringarooma (Appendix 1).

\section{Microhabitat}

Anoglypta launcestonensis is a nocturnal animal which is seldom seen in daylight. It prefers the shelter of rotting logs and moss covered surfaces. Destruction by fire of dense shrub and fern understorey has in places revealed high concentrations of shells suggesting that such shelter may facilitate increased population levels. At one site a high mortality of snails was observed following a fire. Habitat differences are most marked between rainforest and mixed forest where the latter has a high Eucalyptus litter contribution, but no obvious variation associated with this factor has been observed in these snails. The addition of eucalypt bark and leaves to the rainforest litter appears to favour the presence of Helicarion rather than increase the incidence of Anoglypta or Caryodes. 


\section{BOTHRIEMBRYON TASMANICUS (PFEIFFER 1853) \\ Proposed Type Locality: Maria Island}

The species was described by Pfeiffer (1853) who gave the provenance as Van Diémen's Land. In Tasmania Bothriembryon is distributed along the eastern and southern coasts and on some islands (Kershaw 1985). It is a snail of the coastal plain from the backshore to a kilometre or so inland.

Pfeiffer's description established the species only. The length quoted of $25 \mathrm{~mm}$ fits available material but the diameter does not. Dr A. Solem (pers. comm.) has pointed out that Pfeiffer measured diameter oblique to the shell axis thus obtaining a lower figure than would be now recorded. The white shell colour noted by Pfeiffer suggests an old worn shell as noted by Cox (1868). The words used by Pilsbry (1900) are "opaque white" presumably due to the use of similar material although his alternative colours also suggest gerontic shells. Juveniles from all populations are more or less horny translucent. Both of these authors give "East Coast" as the type locality but Iredale (1937a) follows Pfeiffer.

The taxon Bothriembryon brachysoma Pilsbry 1900 also has the type locality "East coast of Tasmania". As there are other populations with a degree of variation it is desirable to clarify this situation.

\section{Original Material}

There are two specimens considered to be possible syntypes in the Cuming Collection in the British Museum of Natural History (P. Mordan in litt. 1982). There are two labels in Pfeiffer's handwriting, one of which refers to Tasmania and the other to New Caledonia. It is impossible to decide which label should be associated with which shell. The dimensions do not conform to the description in either case and one label refers to a variety. As pointed out by Morden this is not technically part of the type series. Although these shells are part of the Cuming Collection and were identified by Pfeiffer it is not possible to decide when Pfeiffer handled them. While the difference in shell diameter can be ignored the failure of the longitudinal dimensions to fit Pfeiffer's published description must be considered. It seems unlikely that Pfeiffer had these shells in hand when he drew up his description.
The Cuming Collection was described by Dance (1966). Cuming may have obtained the shells from one or more of the many visitors to the eastern Tasmanian coast. Errors in original localities in the Cuming Collection are not unknown. The locality "New Caledonia" on one label strongly suggests that the shell was received from a different source although it is an obvious error. This material does not include the type shell.

The history of Maria Island is well known. Many ships visited Darlington (West 1852) where the species is plentiful.

\section{Shell Form and Locality Determination}

Although no specimens as large as those in the British Museum have been seen, both shells have a resemblance to populations found on Maria Island and on the Forestier Peninsula. The difference between shells from these two localities is superficially one of shell colour only. Shells with a pale epidermis occur on Maria Island and this is a very noticeable feature at some sites. Study of shell proportions supports the hypothesis that Maria Island is the source of the Cuming material, including the shell described by Pfeiffer (1853)

Material from Maria Island comparable with Pfeiffer's description is preserved in the Tasmanian Museum. Comparable fresh material has also been studied. The clear resemblance between these shells, the forms recognized by Cox (1868) and Pilsbry (1900) and the original description supports recognition of Maria Island as the source of the original material.

It is believed that Darlington is the original source. The type locality of Bothriembryon tasmanicus (Pfeiffer 1853) is determined as that area bounded by $42^{\circ} 34^{\prime} \mathrm{S}$ to $42^{\circ} 40^{\prime} \mathrm{S}$ and $148^{\circ} 02^{\prime} \mathrm{E}$ to $148^{\circ} 08^{\prime} \mathrm{E}$ which includes North Maria Island.

\section{The Habitat \\ Vegetation}

Bothriembryon tasmanicus is a snail of the dry sclerophyll forest, woodland and coastal scrub. Some adaptation to wet sclerophyll forest is apparent on the Forestier Peninsula and on Maria Island. A specimen has been photographed on the trunk of Banksia marginata on Mt Maria (J. Chick, pers. comm.), the Banksia associated with Callitris rhomboidea, Bedfordia salicina, Olearia argophylla and Richea dracophylla. This community resembles the disjunct flora on eastern screes described by Brown \& Bayley-Stark (1979). 
C. Spry, National Parks ranger, collected specimens on the trunks of Cupressus macrocarpa adjacent to the coast at Darlington and beneath Eucalyptus globulus adjacent to the Bishop \& Clerk track. This latter is an area of Pleistocene talus of dolerite with a vegetation of tall eucalypt woodland. A further collection made on Skipping Ridge represents a population within open forest dominated by Eucalyptus obliqua with a shrubby understorey. This site appears to be on Permian siltstone (Clarke \& Baillie 1984).

The environment is described by Brown \& Bayley-Stark (1979). Further climatic data are presented in Appendix 1.

\section{Geology}

The geology of Maria Island was described by Clarke \& Baillie (1984). At Darlington the shore habitat is one of vegetated dune sands of Holocene age inland from which there is an area of marshy deposits. The bedrock of the type locality includes Jurassic dolerite, Permian and Triassic sedimentary rocks and areas of Quaternary sands. This is typical of the habitat of the species south of Swansea (Forsyth \& Gulline 1978, Farmer 1979).

\section{Microhabitat}

This snail is found for part of the year on trees, rock surfaces and posts where it is dormant during the day. During the winter it apparently seeks shelter under bark, in litter or under stones. During periods of drought it is very difficult to locate and may be buried in the soil as occurs with related forms in South Australia.

\section{BOTHRIEMBRYON BRACHYSOMA PILSBRY 1900}

\section{Proposed Type Locality: Great Oyster Bay coast}

Pilsbry (1900) described this snail as a variety of Bothriembryon tasmanicus with the type locality "East Coast of Tasmania (Petterd)." The holotype of this taxon is preserved in the Academy of Natural Sciences of Philadelphia. The label and catalogue data are those given in Pilsbry (1900) (A.E. Bogan in litt. 1983). Potentially comparable populations have been found on the Freycinet Peninsula (e.g. at Coles Bay), Swansea, Bicheno and Orford. All these populations except those on Freycinet Peninsula are extinct or very nearly so.

\section{Original Material}

The type material consists of one shell clearly collected by W.F. Petterd and there are specimens in the Tasmanian Museum from the Petterd Collection. The latter are E938 (labelled "gunnii Sow.var brachysoma Pils."), E939 (E. Coast Petterd 1889) and E941 (E. Coast). All are comparable and may have been collected in the same locality as $B$. brachysoma. An "Oyster Bay" specimen has dimensions which are almost identical to Pilsbry's shell except for a larger aperture. Legrand (1871) records collections made at Swansea but other records are rare.

Swansea was one of the very early settlements in Tasmania (West 1852, p.547). Freycinet Peninsula was used for grazing purposes requiring frequent contact by sea from Swansea. Hence Petterd could have readily collected throughout the Great Oyster Bay region.

\section{Shell Form}

The dimensions provided by Pilsbry (1900) do not fit either the Orford or the Bicheno form but comparable shells from Coles Bay have been studied. A very close resemblance to the type is unusual but the form is recognizable in Coles Bay material. This is of a shell which is shorter and stouter than B. tasmanicus (see figures in Kershaw 1985). Specimens from the Swansea area are extremely rare. The only viable populations are on the Freycinet Peninsula north of the Hazards and particularly in the vicinity of Coles Bay.

\section{Locality Determination}

The original material probably came from near the shores of Great Oyster Bay either near Swansea or on Freycinet Peninsula. The few Swansea specimens studied are not sufficient to enable a decision but ample material from Coles Bay has been studied. In view of the uncertainty as to the exact site and the probable extent of distribution of the original population, the Great Oyster Bay region is suggested as the type locality of Bothriembryon brachysoma Pilsbry 1900.

This region is bounded by $42^{\circ} 04^{\prime} \mathrm{S}$ to $42^{\circ}$ $10^{\prime} \mathrm{S}$ and $148^{\circ} 04^{\prime} \mathrm{E}$ to $148^{\circ} 20^{\prime} \mathrm{E}$ on the eastern coast of Tasmania.

\section{The Habitat}

\section{Vegetation}

The habits of Bothriembryon brachysoma and B. tasmanicus are very similar if not identical. The vegetation of the Freycinet Peninsula is predominantly dry sclerophyll forest (Kirkpatrick \& Dickinson 1984). At the head of Great Oyster Bay a 
narrow belt of coastal vegetation remains but elsewhere most of the country is cleared with a few scattered trees remaining above the shore. By contrast the Freycinet Peninsula is well forested. Descriptions of the vegetation are given in Kirkpatrick \& Brown (1980) and Tyson (1981).

M. Johnstone (pers. comm.) has observed snails on the wall and windows of the Ranger's house, on tents and under The Chateau at Coles Bay as well as on shrubs and trees. She lists the following vegetation: Casuarina stricta, Leucopogon parviflorus, Acacia sophorae, Eucalyptus globulus and Banksia marginata. The snail is common on the sand vegetation of the Richardsons Beach backshore and is very active after heavy rain.

\section{Geology and Soils}

The spine of the Freycinet Peninsula is of Devonian granite mountains fringed by some narrow strips of Holocene sands (Forsyth \& Gulline 1979). These sands extend across the spit at the northern end of Great Oyster Bay behind Nine Mile Beach toward Swansea where the bedrock is Jurassic dolerite. The soils are mainly yellow duplex podzolic (Nicolls \& Dimmock 1965) but there are uniform sand profiles on the dunes. In most cases the A horizon is distinctly sandy or sandy loam often with a litter cover of Casuarina or Acacia leaves. In some coastal areas the A horizon is very shallow.

\section{Climate}

The mean annual rainfall at Swansea is $614 \mathrm{~mm}$ (Appendix 1). Freycinet Peninsula's rainfall is within the same range as Maria Island and Orford and is distinctly higher than Swansea. Coles Bay may be more closely compa rable in temperature and humidity with Darlington than Swansea (Appendix 1, Brown \& Bayley-Stark 1978). Long periods of drought occur during which Bothriembryon snails are not in evidence.

\section{Microhabitat}

The only apparent difference in the habitat of Bothriembryon tasmanicus and B. brachysoma is the relationship of the latter to the granite bed rock. Both species are found on the same vegetation and in litter from similar plants. B. brachysoma has not been found within wet sclerophyll forest.

\section{CYSTOPELTA PETTERDI TATE 1881 \\ Proposed Type Locality: \\ The Cliff Grounds Reserve and vicinity, \\ Launceston}

This species was described by Tate (1881) without a clear type locality designation. No type or any other original material is known. Tate gave the locality "Near Launceston (W.F. Petterd); Southport (B.R. Dyer)". The Southport animal is unknown.

Iredale (1937b) accepted Launceston as the type locality. Hedley (1891) together with Petterd collected C. petterdi from the "original type locality, Cataract Hill, near Launceston". This should remove any doubt as to the intended locality for this species. However Cataract Hill is now given over to urban development. There are almost no native molluscs left under the remaining vegetation. Cystopelta has not been collected in the area for many years. The species has, however, been found adjacent to a small tributary of the South Esk River about $1.5 \mathrm{~km}$ from Hedley's locality.

\section{Locality Determination}

The population of Cystopelta petterdi extends above the north bank of the tributary from First Basin in the Cataract Gorge to a point almost $1 \mathrm{~km}$ west within the Reserve. Near First Basin there are only a few, scattered individuals. These are at considerable risk due to gardening activity and the presence of peacocks in the Cliff Grounds. The original population certainly occupied a large area in the vicinity of the Cataract Gorge, but the present population appears to be confined to the north side of the Gorge. The description of a neotype chosen from the most viable part of the population (grid $508800 \mathrm{mE} 5411650 \mathrm{mN}$ ) has been submitted elsewhere (Kershaw 1987).

The suggested type locality is that area bounded by $41^{\circ} 26^{\prime} \mathrm{S}$ to $41^{\circ} 30^{\prime} \mathrm{S}$ and $147^{\circ} 02^{\prime} \mathrm{E}$ to $147^{\circ} 08^{\prime} \mathrm{E}$. This area is inclusive of the original site described by Hedley (1891) and the neotype locality. It also includes the Cliff Grounds Reserve. The area is at high risk from fire and other activities but no other appropriate site has been found.

\section{The Habitat}

\section{Vegetation}

Cystopelta petterdi is a species of dry sclerophyll forest, woodland and scrub in damp places such as gullies and drainage lines. It is also found in 
areas of wet sclerophyll to mixed forest within its Tamar Valley distribution. For example, variations of the animal are found in the Notley Fern Gorge and in wet eucalypt forest at Frankford. Similar variations are present in northeastern Tasmania but the rainforest and mixed forests of this region shelter a different morph.

The vegetation of the West Tamar as described by Brown \& Buckney (1983) includes much of the habitat but not the type locality. This area is included in the Tippogoree land system of Pinkard (1980) of open forest dominated by eucalypts. In the neotype locality the species occupies the southfacing slope which is significantly moister than the north-facing slope of the tributary valley (a moisture content relationship in accord with the findings of Nunez, 1983).

The vegetation observed in the neotype locality includes: Themeda australis, Cassinea aculeata, Senecio linearifolius, Acacia dealbata, $A$. mearnsii, Eucalyptus amygdalina, E. ovata, E. viminalis, Notolaea ligustrina, Clematis gentianoides, Coprosma quadrifida, Exocarpos cupressiformis, Polystichum proliferum and Pteridium esculentum together with bryophytes. The creek banks adjacent to the type locality population have Blechnum nudum, B. wattsii, Dicksonia antarctica, Acacia melanoxylon and Pomaderris apetala but these species are absent where the valley widens westerly to open woodland. The vegetation fits the shrubby group within dry sclerophyll forest as defined by Duncan \& Brown (1984). Cystopelta occurs above the creek bank as occasional individuals. It appears to prefer the slightly better drainage of the slope. The species has not been seen on the dry north-facing slope although there are small areas that appear to be suitable.

The area on Cataract Hill described by Hedley ( 1891 ) is believed not to include the north aspect facing the Cataract Gorge. Hedley (1891) collecting with Petterd found the species under logs. While still found in such situations the animals are clearly less common. They also occur in coils of bark and occasionally in litter. They have not been found on tree trunks in this area but elsewhere, in rainforest, a nimals are present on tree trunks for much or all of the year

\section{Geology and Soils}

The neotype locality has a Jurassic dolerite bedrock (McClenaghan \& Baillie 1975) deeply dissected by the Cataract Gorge. There has been downslope movement in some areas resulting in deeper friable loams. A typical profile is a dark brown loam $\mathrm{A}$ horizon over a reddish brown clay $\mathrm{B}$ horizon. Patches of dark greybrown loam occur.

\section{Climate}

The annual rainfall at Trevallyn, the nearest station, is $760 \mathrm{~mm}$. Climatic data for Launceston are given in Appendix 1. Frosts and fogs are common (Bureau of Meteorology 1985). The neotype locality is significantly more sheltered and humid than the adjoining terrain.

\section{Microhabitat}

Cystopelta petterdi requires a significantly higher shelter and moisture level than required by introduced slugs. Cystopelta does not penetrate the drier woodland within which introduced species can survive. It is also absent from partly cleared timbered areas where there is little effective shelter at ground level and exposure reduces the moisture level. It is never found in gardens or other cultivated environments. Cystopelta favours the shelter of clean strips of coiled eucalypt bark. The most successful populations are found where bark is plentiful and moisture level reliable. This is particularly the case where bark rests on prolific blackberry growth. Cystopelta petterdi is semi-arboreal and appears distinct at least in this respect from the apparently totally arboreal morph seen in rainforest in northeastern Tasmania.

\section{CYSTOPELTA BICOLOR PETTERD \& HEDLEY, 1909}

\section{Proposed Type Locality:} Near the Magnet Mine, Western Tasmania

This species was described by Petterd \& Hedley (1909) who give the habitat as "Magnet Range and Upper Pieman River". At the time Petterd was manager of the Magnet Mine and hence undoubtedly had opportunities to search for molluscs. This factor is also an indication of the part of the Magnet Range in which he may have collected. The country is rugged with large areas densely forested and access is difficult. For these reasons the species has been difficult to find and hitherto has been considered unknown.

\section{Original Material}

There are two lots of possible syntype material. Two dried specimens are preserved in the Australian Museum (AM C27807) and one dried specimen is preserved in the Queen Victoria Museum (QVM409 1983/9/4). The identity of these specimens is not recognizable superficially. 
The criteria upon which Cystopelta bicolor was erected are not visible in dried specimens. In addition a different morph has been found living in the area. Consequently the dried specimens are of little practical value.

\section{Form}

It is essential to establish the morphology of the species to enable recognition and establish the validity of the taxon. Specimens collected adjacent to the road to the Magnet Mine in June 1986 have made this possible. These animals compare favourably with the original description including a brown mantle, a green foot and green caudal mucus. This combination of features upon which $C y$ stopelta bicolor is based is not present in $C$. petterdi. Individually these features are not enough to distinguish the species and specimens with a green foot are found elsewhere. This taxon has precedence over all others except $C$. petterdi. Therefore the erection of a neotype from the type locality with a description of the anatomy is essential (Kershaw 1987).

\section{Locality Determination}

No material has been found in the Upper Pieman River region. The assumption that Petterd collected most of his material near the Magnet Mine together with the results of recent field work (above) favour the Magnet region as the type locality.

The area bounded by $41^{\circ} 24^{\prime} \mathrm{S}$ to $41^{\circ} 30^{\prime} \mathrm{S}$ and $145^{\circ} 24^{\prime} \mathrm{E}$ to $145^{\circ} 30^{\prime} \mathrm{E}$ in the vicinity of the Magnet Range and the Magnet Mine near Waratah, western Tasmania, is proposed as the type locality of Cystopelta bicolor Petterd \& Hedley 1909. This differs from Iredale (1937b) only in the omission of the Upper Pieman area.

\section{The Habitat \\ Vegetation}

The habitat of this species is rainforest. All Cystopelta are arboreal to some degree hence this is not a distinguishing feature without further clarification. The colour pattern of the animal coincides remarkably with the stem and foliage colour of shrubs and young trees in the habitat. The green foot of the specimens found was dull rather than bright as described and fades rapidly in preservative. Specimens with a bright green foot have been found in central Tasmania. It is possible that the colour varies with season and environment. Juveniles have a bright translucent green foot colour.

The Magnet Road material was found in scrub regrowth adjacent to the road in a very old log buried in the ground. This has some similarity with the original "scrub" site. The vegetation in and immediately adjacent to the site includes: Nothofagus cunninghamii, Acacia melanoxylon, Atherospermum moschatum, Bauera rubioides, Gahnia grandis, Cyathodes parvifolia, Eucryphia lucida, Leptospermum scoparium, Telopea truncata, Tasmannia lanceolata, Phyllocladus aspeniifolius, Cassinia aculeata and Juncus sp. Some of these species are present as mature trees adjoining regrowth.

No specimens were found in the adjacent rainforest either in logs or on trees. They may have been present in the foliage but could not be seen even with torch light. The authors remark on the rarity of their species. Two additional specimens were found to the north of the Hellyer Gorge adjacent to the Murchison Highway. Prolonged search failed to reveal any further specimens but in December 1986 B. Blandford found the species within the Hellyer Gorge.

The Murchison Highway site differed substantially from that of Magnet Road. The vegetation included Eucalyptus obliqua, Acacia melanoxylon, Nothofagus cunninghamii, Olearia argophylla, Pittosporum bicolor, Dicksonia antarctica, Tasmannia lanceolata, all of mature growth together with Pteridium, fireweed and blackberry along the roadside. The Cystopelta were found in coiled bark adjacent to the blackberry.

The rainforest in the type locality is similar to that described by Kirkpatrick (1977) as large crowned rainforest.

\section{Geology and Soils}

A large proportion of the type area is classified as the Mt Bischoff Land System on Permian mudstone and slates while the Murchison Highway site is part of the Hampshire Land System on Tertiary basalt (Richley 1978). The Magnet Road site adjoins a quarry in Cambrian rocks (Williams $\&$ Turner 1974). The soil has a large proportion of slatey siltstone and mudstone. It is a stoney yellow clay with a shallow humus A horizon with a moss cover in the forest. Adjoining the Murchison Highway a shallow humus clay loam A horizon with a deep brownish yellow $\mathbf{B}$ horizon over fragmentary bedrock can be seen in the roadside. Detail on the soils is provided by Richley (1978). 


\section{Climate}

Nye (1923) observed that rainfall at Magnet was higher than at Waratah. The valley of Magnet Creek is $150 \mathrm{~m}$ below Waratah and the neotype locality is a short distance above the Magnet valley floor. He provided tables of monthly rainfall at Waratah. The nearest modern data on rainfall, temperature and humidity (Appendix 1) are from Savage River.

\section{Microhabitat}

Cystopelta bicolor has been found in strips of coiled eucalypt bark as well as below logs. Superficially there is a resemblance to the habits of $C$. petterdi but Petterd \& Hedley (1909) recorded $C$. bicolor from foliage. The latter species favours much higher humidity.

\section{ACKNOWLEDGEMENTS}

Thanks are due to Drs E. Binder (Geneva), A.E. Bogan (Philadelphia), D. Heppeli (Edinburgh), P. Mordan(London), S. Tillier (Paris) and B.J. Smith (Melbourne), Miss A. Green and Mrs E. Turner (Hobart) and Mrs M.P. Cameron (Launceston). Field help was given by Dr R. Mesibov and Messrs M. Jessup, R.M. Smith, M. Smith, P. Duckworth, M. Stranger and many of their colleagues of the Forestry Commission; D. Rounsevell, C. Spry, Dr S. Smith and colleagues of the National Parks and Wildlife Service; Mr A. Daniell and Dr B.J. Smith. Mr N.J.B. Plomley kindly allowed the use of his copy of Labillardiere (1800). I particularly thank Mrs M. Johnstone and her husband Ranger H. Johnstone of Coles Bay and Mrs B. Blandford of Melbourne. My wife Winifred has checked the manuscript, identified a large proportion of the plants observed, consulted with Mrs M.P. Cameron and helped greatly in the field. The trustees of the Science and Industry Endowment $F$ und are thanked for significant support of this research.

\section{REFERENCES}

BROWN, M.J. \& BUCKNEY, R.T., 1983: Structural and floristic variation in the forest communities of the West Tamar, Tasmania. Pap. Proc. $R$. Soc. Tasm., 117: 135-147.

BROWN, M.J. \& BAYLEY-STARK, H.J., 1979: Vegetation of Maria Island. Wildl. Divn Tech. Rept 79/1. National Parks and Wildlife Service, Tasmania: 1-99.

BUREAU OF METEOROLOGY, 1985: Climate in Tasmania. In Cocking, G.D. (Ed.): TASMAN.
$I A N$ YEAR BOOK. Government Printer, Hobart: $34-47$

BURNS, T.E. \& SKEMP, J.R., 1961: Van Diemen's Land Correspondents. Rec. Q. Vict. Mus. Launceston. N.S. No. 14: i-xix, 1-142.

CHRISTIAN, C.S. \& SHARP-PAUL, A., 1979: Description of the biophysical environment. Lower Gordon River Scientific Survey. Hydro-Electric Commission, Hobart: 1-139.

CLARKE, M.J. \& BAILLIE, P.W, 1984: Geological Atlas 1:50 000 Series Sheet 77 (8512N) Maria. Explan. Rep. Dept Mines Tasm.: 1-39.

COX, J.C., 1868: MONOGRAPH OF AUSTRALIAN $L A N D S H E L L S$. William Maddock, Sydney: $111 \mathrm{pp}$.

DANCE, S.P., 1966: SHELL COLLECTING. AN ILLUSTRATED HISTORY. Faber and Faber, London: $344 \mathrm{pp}$.

DUNCAN, F. \& BROWN, M.J. 1985: Dry sclerophyll vegetation in Tasmania. Extent and conservation status of the communities. Wildl. Divn Tech Rept 85/1. National Parks and Wildlife Service, Tasmania.

FARMER, N., 1979: Geological Atlas 1:250000 Series. Sheet SK-55/8 Hobart. Explan. Rept geol. Surv. Tasm.: 1-24

FORSYTH, S.M. \& GULLINE, A.B., 1979: Geological Atlas 1:250 000 Series. Sheet SK-55/6. Oatlands. Explan. Rept geol. Surv. Tasm.: I-15.

GIBLIN, W., 1928: THE EARLY HISTORY OF TASMANIA. THE GEOGRAPHICAL ERA 1642-1804. Methuen, London: 341 pp.

GILBERT, J.M., 1959: Forest succession in the Florentine Valley, Tasmania. Pap. Proc. R. Soc. Tasm. 93: $129-151$.

HEDLEY, C., 1891: On the anatomy of some Tasmanian snails. Proc. Linn. Soc. N.S.W.: 19-26.

HOOKWAY, E., JENNINGS J. \& PAGE, P. (Eds) 1981: SCOTT'S NEW COUNTRY. Second edition. Scott's New Country Committee Scottsdale: 228 pp.

IREDALE, T., 1937a: A basic list of the Mollusca of Australia. Aust. Zool., 8(4): 287-333.

IREDALE, T., $1937 \mathrm{~b}$ : A basic list of the Mollusca of Australia. 2. Aust. Zool, 9(1): 1-39.

JACKSON, W.D., 1965: Vegetation. In Davies, J.L. (Ed.): $A T L A S$ OF TASMANIA. Lands and Surveys Department, Hobart: $30-35$.

JACKSON, W.D., 1974: Conservation in Tasmania. In Specht, R.L., Roe, E.M. \& Boughton, V.H. (Eds): CONSERVATION OF MAJOR PLANT COMMUNITIES IN AUSTRALIA AND PAPUA NEW GUINEA. Aust. J. Bot. Suppl. Ser. No.7.

JARMAN, S.J. \& BROWN, M.J., 1983: A definition of cool temperate rainforest in Tasmania. Search, 14(3-4): $81-87$

KERSHAW, R.C., 1985: The distribution of Bothriembryon tasmanicus (Pfeiffer, 1853) (Pulmonata: Bulimulidae). Tasm. Nat. No.80: 3-7. 
KERSHAW, R.C., 1987: Redescriptions of Cystopelta petterdi Tate, 1881 and Cystopelta bicolor Petterd and Hedley, 1909 (Pulmonata: Cystopeltidae). $J$. Malac. Soc. Aust., in press.

KERSHAW, R.C. \& DARTNALL, A.J., 1972: The mollusc Caryodes dufresnii in Tasmania. Vict. Nat., 89(4): 111-118.

KIRKPATRICK, J.B., 1977: native vegetation of the West Coast region of Tasmania. In Banks, M.R. \& Kirkpatrick, J.B. (Eds): LANDSCAPE AND $M A N$. Royal Society of Tasmania, Hobart: 55-80.

KIRKPATRICK, J.B. \& BACK HOUSE, S., 1983: $A N$ ILLUSTRATED GUIDE TO TASMANIAN NATIVE TREES. Tasmanian Conservation Trust, Hobart: $122 \mathrm{pp}$.

KIRKPATRICK, J.B.\& BROWN, M.J., 1980; THREATENED PLANTS OF THE TASMANIAN CENTRAL EAST COAST. Tasmanian Conservation Trust, Hobart.

KIRKPATRICK, J.B. \& DICKINSON, K.J.M., 1984 VEGETATION MAP OF TASMANIA, 1:500 000. Tasmanian Forestry Commission, Hobart.

LABILLAR DIERE, J.J.H.De, 1800: VOYAGE IN $S E A R C H$ OF LA PEROUSE PERFORMED BY ORDER OF THE CONSTITUENT ASSEMBLY DURING THE YEARS 1791, 1792, 1793 AND 1794. (English Translation) John Stockdale, London: Volume II

LEACH, W.E., 1815: ZOOLOGICAL MISCELLANY. London, Volume 2: 154.

LEGRAND, W., 1871: COLLECTIONS FOR $A$ MONOGRAPH OF TASMANIAN LAND SHELLS. W. Legrand, Hobart.

McCLENAGHAN, M. \& BAILLIE, P.W., 1975: Geological Atlas 1:250 000 Series. Sheet SK-55/4. Launceston. Explan. Rept geol. Surv. Tasm.: $1-15$.

McCLYMONT, J.R., 1885: Tentative list of the navigators who visited Van Diemen's Land prior to September, 1803. Pap. Proc. R. Soc. Tasm. (1884): 253-263.

MILLIGAN, J., 1849: Report on the coal basins of Van Diemen's Land. Whale's Head and South Cape. Pap. Proc. R. Soc. Tasm., I(1): 17-29.

NICOLLS, K.D. \& DIMMOCK, G.M., 1965: Soils. In Davies, J.L. (Ed.): ATLAS OF TASMANIA. Lands and Surveys Department, Hobart: 26-29.

NUNEZ, M., 1978: Climate. In Gee, H. \& Fenton, J. (Eds): THE SOUTH WEST BOOK. A TAS$M A N I A N$ WILDERNESS. Australian Conservation Foundation, Melbourne: 67-69.

NUNEZ, M., 1983: Estimation of solar radiation received on slopes in Tasmania. Pap. Proc. R. Soc. Tasm., 117: 153-159.

NYE, P.B., 1923: The silver-lead deposits of the Waratah District. Geol. Surv. Bull. No. 33: 1-192.

PETTERD, W.F. \& HEDLEY, C., 1909: A revised census of the terrestrial Mollusca of Tasmania Rec. Aust. Mus., 7: 283-304.
PFEIFFER, L., 1853: Description of fifty four new species of helices, from the collection of Hugh Cumming, Esq. Proc. Zool. Soc. London 1851, part 19: 252-263.

PILSBRY, H.A., 1900: MANUAL OF CONCHOLOGY series 2. 13. Academy of Natural Sciences of Philadelphia, Philadelphia: $253 \mathrm{pp}$.

PINKARD, G.J., 1980: LAND SYSTEMS OF TAS$M A N I A$. Region 4. Tasmania Department of Agriculture, Hobart: 278 pp.

PLOMLEY, N.J.B., 1984: Pre-settlement exploration of Tasmania and natural sciences: the Clive Lord Memorial Lecture 1983. Pap. Proc. R. Soc. Tasm., 118: 69-78.

PRETYMAN, E.R., 1954: Pirates at Recherche Bay or the loss of the Brig "Cyprus". Pap. Proc. R. Soc. Tasm., 88: 119-128.

REEVE, L., 1853a: CONCHOLOGICA ICONICA. Species 968 (Mus. Cuming). L. Reeve, London.

REEVE, L., 1853b: Description of a new species of Helix from Van Diemen's Land. Proc. Zool. Soc. London 1852: 31, pl.xiii.

RICHLEY, L.R., 1978: LAND SYSTEMS SURVEY OF TASMANIA - REGION 3. Tasmania Department of Agriculture, Hobart.

SMITH, B J \& KERSHAW, R C 1981: TASMANIAN LAND\& FRESHWATER MOLLUSCS. Fauna of Tasmania Handbook No.5. University of Tasmania, Hobart: $148 \mathrm{pp}$

TATE, R., 1881: On some Australian slugs, chiefly Tasmania. Pap. Proc. R. Soc. Tasm., 1880; 15-18.

TENISON-WOODS, J.E., 1878: On Bulimus Dufresnii. Proc. Linn. Soc. N.S.W., 3(2): 81-91.

TWELVETREES, W.H., 1915a: The Catamaran and Strathblane coalfields and coal and limestone at Ida Bay (Southern Tasmania). Geol. Surv. Bull. No. 20: 1-61.

TWELVETREES, W.H., 1915b: Reconnaissance of country between Recherche Bay and New River, Southern Tasmania. Geol. Surv. Bull. No.24: South.

TYSON, R.G., 1981: Some notes on regrowth of vegetation following a wildfire in Freycinet National Park. Tasm. Nat. No.67: 16.

WATERMAN, P. \& PATERSON, I., 1981: The conservation of natural vegetation in south west Tasmania. South West Tasmania Resources Survey Working Paper No.4: 1-83. Appendices $1-5$.

WELLS, S.M., PYLE, R.M. \& COLLINS, N.M. (Eds) 1983: THE IUCN INVERTEBRATE RED $D A T A$ BOOK. IUCN Gland, Switzerland: $632 \mathrm{pp}$.

WEST, J., 1852: THE HISTORY OF TASMANIA. A.G.L. Shaw Edition. Angus \& Robertson, London: $699 \mathrm{pp}$

WILLIAMS, E. \& TURNER, N.J., 1974: Geological Atlas 1:250 000 Series. Sheet SK-55/3. Burnie. Explan. Rept geol. Surv. Tasm.: 1-16.

(accepted 3 March 1987) 


\section{APPENDIX 1}

Climatic Data Relevant to Type Localities

Part A: Mean seasonal and annual rainfall ( $\mathrm{mm})$

\begin{tabular}{|c|c|c|c|c|c|c|}
\hline Mollusca & Locality & Sum. & Aut. & Win. & Spr. & Ann.* \\
\hline \multirow[t]{2}{*}{ Caryodes } & Maatsuyker Is. & 240 & 320 & 371 & 313 & 1244 \\
\hline & Cape Bruny & 195 & 239 & 276 & 239 & 949 \\
\hline \multirow[t]{2}{*}{ Anoglypta } & Scottsdale & 176 & 288 & 361 & 267 & 1092 \\
\hline & Ringarooma & 198 & 279 & 440 & 314 & 1231 \\
\hline \multirow[t]{3}{*}{ Bothriembryon } & Darlington & 167 & 165 & 177 & 160 & 669 \\
\hline & Orford & 157 & 188 & 186 & 185 & 716 \\
\hline & Swansea & 152 & 156 & 198 & 148 & 614 \\
\hline \multirow[t]{4}{*}{ Cystopelta } & Trevallyn & 136 & 190 & 248 & 186 & 760 \\
\hline & Launceston & 132 & 167 & 237 & 184 & 720 \\
\hline & Savage River & 300 & 503 & 660 & 494 & 1957 \\
\hline & Waratah & 352 & 517 & 732 & 601 & 2202 \\
\hline \multicolumn{7}{|c|}{ Part B: Mean daily temperature ( $\mathrm{C}$ ) } \\
\hline \multirow[t]{4}{*}{ Caryodes } & Maatsuyker Is. & 17 & 14 & 11 & 13 & $16 \mathrm{Max}$. \\
\hline & & 10 & 9 & 7 & 7 & $8 \mathrm{Min}$ \\
\hline & Cape Bruny & 18 & 16 & 11 & 14 & $15 \mathrm{Max}$ \\
\hline & & 11 & 9 & 6 & 8 & $8 \mathrm{Min}$. \\
\hline \multirow{2}{*}{ Anoglypta } & Scottsdale & 21 & 17 & 12 & 16 & 16 Max. \\
\hline & & 10 & 7 & 3 & 6 & 6 Min. \\
\hline \multirow[t]{4}{*}{ Bothriembryon } & Orford & 22 & 19 & 14 & 17 & $18 \mathrm{Max}$ \\
\hline & & 11 & 8 & 3 & 7 & $7 \mathrm{Min}$. \\
\hline & Swansea & 21 & 18 & 14 & 17 & $17 \mathrm{Max}$ \\
\hline & & 11 & 8 & 4 & 7 & $7 \mathrm{Min}$. \\
\hline \multirow[t]{6}{*}{ Cystopelta } & Launceston & 24 & 19 & 13 & 18 & $18 \mathrm{Max}$ \\
\hline & & 11 & 7 & 3 & 7 & 7 Min. \\
\hline & Savage River & 19 & 15 & 10 & 13 & $14 \operatorname{Max}$ \\
\hline & & 9 & 7 & 4 & 5 & $6 \mathrm{Min}$. \\
\hline & Waratah & 17 & 13 & 8 & 12 & $12 \mathrm{Max}$. \\
\hline & & 6 & 4 & 1 & 3 & $3 \mathrm{Min}$. \\
\hline \multicolumn{7}{|c|}{ Part C: Average humidity (\%) } \\
\hline \multirow[t]{4}{*}{ Caryodes } & Maatsuyker Is. & 82 & 85 & 86 & 83 & 84 a.m. \\
\hline & & 77 & 81 & 82 & 79 & 80 p.m. \\
\hline & Cape Bruny & 76 & 81 & 84 & 78 & 80 a.m. \\
\hline & & 73 & 75 & 77 & 73 & 74 p.m. \\
\hline \multirow[t]{2}{*}{ Anoglypta } & Scottsdale & 71 & 77 & 82 & 74 & $76 \mathrm{a} . \mathrm{m}$ \\
\hline & & 62 & 65 & 73 & 68 & 67 p.m. \\
\hline \multirow[t]{4}{*}{ Bothriembryon } & Orford & 66 & 77 & 84 & 68 & 74 a.m. \\
\hline & & 58 & 65 & 68 & 61 & 63 p.m. \\
\hline & Swansea & 66 & 73 & 77 & 66 & 70 a.m. \\
\hline & & 59 & 62 & 64 & 60 & 61 p.m. \\
\hline \multirow[t]{6}{*}{ Cystopelta } & Launceston & 61 & 81 & 89 & 71 & 76 a.m. \\
\hline & & 45 & 59 & 68 & 56 & 58 p.m. \\
\hline & Savage River & 79 & 87 & 91 & 83 & 86 a.m. \\
\hline & & 61 & 76 & 83 & 71 & 73 p.m. \\
\hline & Waratah & 79 & 88 & 93 & 85 & 86 a.m. \\
\hline & & 67 & 80 & 87 & 77 & 78 p.m. \\
\hline
\end{tabular}

* Seasons - Sum. = summer, Aut. = autumn, Win. = winter, Spr. = spring.

Notes: These data are provided by courtesy of the Commonwealth Bureau of Meteorology. The stations selected are the nearest for which data are available. The periods of observation range from 19 years for Scottsdale and Orford to 85 years for Launceston. 